\author{
RADOSEAW BUDZYŃSKI \\ Katedra Międzynarodowych \\ Studiów Polonistycznych \\ Uniwersytet Jagiellonski
}

\title{
O NIEZNANYCH LISTACH GUSTAWA MANTEUFFLA ZE ZBIORÓW BIBLIOTEKI UNIWERSYTETU LWOWSKIEGO. KOMUNIKAT
}

\begin{abstract}
Abstrakt: W zbiorach Biblioteki Uniwersytetu Lwowskiego zostały odnalezione listy Gustawa Manteuffla do Aleksandra Semkowicza. Ich wartość polega na uzupełnieniu „białych plam” w biografii polsko-inflanckiego barona w zakresie jego współpracy z redakcją lwowskiego „Kwartalnika Historycznego" oraz z galicyjskimi historykami polskimi. Korespondencja ta przynosi informacje, jak technicznie rozwiązywano problem przekazywania periodyku do kraju, w którym był on zakazany. Co więcej, listy Manteuffla rzucają też światło na jego relacje z rosyjską cenzurą. $\mathrm{Na}$ uwagę zasługuje również krótka wzmianka na temat czasów studenckich Manteuffla w Dorpacie.
\end{abstract}

Słowa kluczowe: Gustaw Manteuffel, historiografia, Inflanty Polskie, Lwów, korespondencja.
Abstract: Until recently, little has been known about the cooperation of baron Gustaw Manteuffel (1832-1916), an outstanding chronicler of Polish Livonia, with the Kwartalnik Historyczny, published in Lwów (L'viv, Lemberg). Manteuffel's letters to Aleksander Semkowicz have recently been found in the collection of the Library of the University of L'viv. These are especially valuable as they will fill the gaps in the biography of the Polish-Livonian baron. One such gap is his cooperation with the editorial staff of the Kwartalnik Historyczny and Polish historians from Galicia. The correspondence sheds light on such matters as the way in which the periodical was smuggled into the country, where it was forbidden, and Manteuffel's relations with Russian censorship. There is a brief mention of Manteuffel's student years at Tartu.

Keywords: Gustaw Manteuffel, historiography, Polish Livonia, L'viv, letters.

Niniejszy tekst jest poświęcony czterem, nieznanym dotychczas polskim badaczom, listom Gustawa Manteuffla do redakcji „Kwartalnika Historycznego" z lat 1903-1904 ze zbiorów Biblioteki Uniwersytetu 
Lwowskiego (sygn. rkp. 999 II) ${ }^{1}$. O współpracy barona Gustawa Manteuffla (1832-1916), wybitnego dziejopisa Inflant Polskich, z lwowskim „Kwartalnikiem Historycznym” dotychczas nie było wiadomo zbyt wiele ${ }^{2}$. Juliusz Bardach w notce poświęconej Manteufflowi w Polskim słowniku biograficznym lakonicznie stwierdził: „Był stałym współpracownikiem «Kwartalnika Historycznego», zamieszczając w nim recenzje wszystkich niemal prac dotyczących Inflant"3. Również inni badacze ${ }^{4}$ nie podawali uzupełniających informacji na ten temat.

Niestety, nie wiadomo, jakie były okoliczności nawiązania współpracy redakcji „Kwartalnika Historycznego” z Manteufflem. Można podejrzewać, że zaangażował go do nadsyłania artykułów pierwszy redaktor czasopisma - Ksawery Liske ${ }^{5}$. Jednakże prawdopodobnie cała korespondencja Manteuffla na ten temat uległa zniszczeniu w czasie II wojny światowej w Warszawie ${ }^{6}$. To, co ocalało z pożogi wojennej, jest rozproszone w różnych instytucjach krajowych i zagranicznych ${ }^{7}$. Część korespondencji z historykami lwowskimi zachowała się w zbiorach Zakładu Narodowego im. Ossolińskich we Wrocławiu (sygn. rkp. nr 6296/I k. 113-21; nr 7699/II k. 185; nr 7701/II k. 11-95). Jako iż po II wojnie światowej Polacy byli zmuszeni do pozostawienia części swojego dziedzictwa po sowieckiej stronie granicy ${ }^{8}$, można przypuszczać, że niektóre materiały, nieopracowane, wciąż znajdują się we Lwowie.

${ }^{1}$ Sam zbiór listów został wspomniany w pracy Alfreda Toczka, jednak bez wskazania na zachowane pisma Gustawa Manteuffla, por. A. Toczek, Lwowskie środowisko historyczne i jego wkład w kulturę ksiażki i prasy (1860-1918), Kraków 2013, s. 419.

${ }^{2}$ W Archiwum Polskiej Akademii Nauk w Warszawie w zespole Polskiego Towarzystwa Historycznego znajdują się m.in. listy Gustawa Manteuffla do historyków lwowskich, które wciąż czekają na przebadanie.

${ }^{3}$ J. Bardach, Manteuffel-Szoege Gustaw (1832-1916), PSB, t. 19, Kraków 1974, s. 492.

${ }^{4}$ Por. H. Strods, Gustaw Manteuffel (Manteuffel-Szoege, 1832-1916). Życie i twórczość, w: Kultura polska na Łotwie, red. J. Sozański, R. Szklennik, Ryga 1994 s. 146; R. Manteuffel-Szoege, Inflanty, Inflanty, oprac. Z. Szopiński, Warszawa 1991, s. 261-263; K. Zajas, Gustaw Manteuffel projektuje Inflanty, w: G. Manteuffel, Inflanty Polskie i Listy znad Battyku, Kraków 2009, s. XII, oraz idem, Nieistniejaca kraina, zapomniany historyk, w: G. Manteuffel, Zarysy z dziejów krain dawnych inflanckich..., oprac. idem, Kraków 2007, s. X.

${ }_{5}^{5}$ Takie sugestie pochodzą ze wzmianek samego inflanckiego dziejopisa wyrażanych $\mathrm{w}$ korespondencji z innymi autorami.

${ }^{6}$ O zniszczeniu spuścizny piśmienniczej Manteuffla, znajdującej się w rodowym archiwum por. R. Manteuffel-Szoege op. cit., s. 15. Poza tym trzeba jeszcze uwzględnić stratę jego „Tek literackich”, które zostały przed II wojną światową przekazane przez Tadeusza Manteuffla Bibliotece Narodowej w Warszawie.

${ }^{7}$ Przykładowo niewielkie zbiory korespondencji Gustawa Manteuffla znajdują się w Krakowie, Bydgoszczy, Warszawie czy we Wrocławiu.

${ }^{8} \mathrm{~Np}$. dzieje lwowskich zbiorów Zakładu Narodowego im. Ossolińskich: https:// ossolineum.pl/index.php/aktualnosci/zbiory-lwowskie/ (dostęp: 27 XI 2017). 
Wydawać by się mogło, że odnalezione listy nie będą w żaden istotny sposób wpływały na postrzeganie postaci Gustawa Manteuffla, ale biorąc pod uwagę wielkość strat wynikających ze zniszczenia dziedzictwa materialnego pozostałego po tym dziejopisie w latach 1939-1945 w stolicy, każdy zachowany ślad jego działalności, a już szczególnie taki, który nie był znany polskim badaczom, posiada wyjątkową wartość ${ }^{9}$ Tym bardziej że opisywane listy nie są skatalogowane, ani nawet ponumerowane w obrębie danej sygnatury, a wymieszane pomiędzy listami innych autorów. Znajdują się w kopercie z początków XX w. i gdyby zaginęły, zostały skradzione lub uległy zniszczeniu, o co przecież nietrudno, to w ogóle nie byłoby po nich żadnego, nawet najmniejszego, śladu ${ }^{10}$. Zresztą jest to przypadek nie tylko listów polsko-inflanckiego badacza. W tej samej kopercie, pod tą samą sygnaturą, znajduje się także korespondencja innych ważnych polskich historyków i ludzi kultury, na przykład listy Stanisława Smolki, również nieoznaczone osobnymi numerami.

Wracając zaś do listów Gustawa Manteuffla, wszystkie cztery pisane były z Rygi, dwa z nich mają wskazaną ulicę Grosse Neustrasse 37 (z 22 I 1903 oraz z 18 XII 1903), ale można przypuszczać, że i pozostałe dwa (z 14 XII 1903 i z 3 II 1904) powstały pod tym adresem. Koperta, w której znajdowały się wraz z listami innych osób, była zatytułowana ogólnie „Administracja Kwartalnika Historycznego”. Na szczęście na kartce pocztowej, przesłanej do Lwowa przez Manteuffla w 1904 r., było podane nazwisko adresata. Załatwiał on wówczas swoje sprawy z Aleksandrem Semkowiczem. Pozostałe trzy listy pisane były czarnym atramentem na papierze czerpanym. Listy z 14 i 18 grudnia 1903 r. były pisane na papierze czerpanym firmy Margaret Mill Hand Made Vienna Manufacture. List z 22 stycznia 1903 r. został zapisany na papierze z nieustalonej fabryki papierniczej. Charakter pisma nadawcy jest czytelny, z wyjątkiem obcojęzycznych wyrażeń, które wplatał w tekst, zazwyczaj niemiecko- lub francuskojęzycznych.

Pierwszy z zachowanych listów pochodzi z 22 stycznia 1903 r., jednakowoż z jego treści wynika, że musiała zajść pomyłka przy datowaniu przez Manteuffla, gdyż powołuje się on na pismo z 24 września 1903 r.,

${ }^{9}$ Por. K. Zajas, Gustaw Manteuffel projektuje Inflanty, s. VIII: „Jeżeli uświadomimy sobie, że te archiwa rodzinne w zdecydowanej większości dzisiaj nie istnieją, to uwagi o niedostatecznej reprezentacji Inflant Polskich nabierają szczególnego charakteru".

10 „Gdy piszę o tym po czterdziestu latach do jeszcze wyraźniejszego uświadomienia tych dysproporcji dołącza się świadomość, że to, czego wówczas nie opracowano, czego nie ogłoszono drukiem, nie sfotografowano itd. - przepadło z kretesem, zwęglone i spopielone w latach wojennych", M. Danilewicz-Zielińska, Wspomnienia o Bibliotece Narodowej w Warszawie, „Zeszyty Historyczne” 1987, 46, s. 56. 
a bardzo mało prawdopodobne wydaje się odczytanie roku powstania listu jako „1905”, choć oczywiście nie można tego zupełnie wykluczyć11. Manteuffel zwracał się z prośbą do „Szanownego Pana Redaktora” Semkowicza o dosłanie brakujących numerów „Kwartalnika Historycznego”, które zawierały jego teksty. Przy tym nie tracił nadziei na otrzymanie lwowskiego czasopisma, ponieważ wierzył, że: „zawitają również [te numery „Kwartalnika Historycznego” - R.B.] kiedykolwiek do Rygi”. Jest ta wiara Manteuffla poparta słowem Wilhelma Rolnego, który „zapowiedział mi uroczyście wysłanie onych już przed 5ciu tygodniami”. A więc nadawca wykazuje się niesłychaną cierpliwością, czekając nie tylko wiele tygodni, ale nawet wiele miesięcy na periodyki. Z cytowanego zdania pochodzi jeszcze jedna interesująca informacja, dotycząca zasięgu kontaktów korespondencyjnych Gustawa Manteuffla. Do tej pory można było domyślać się jego powiązań z Liskem, Oswaldem Balzerem czy Ludwikiem Finklem. Obecnie zaś krąg jego korespondentów powiększył się na razie o dwie kolejne osoby: Semkowicza i Rolnego. Nie darząc rosyjskiej Warszawy zbytnią estymą, Manteuffel utrzymywał kontakty z historykami galicyjskimi, ze środowiskami historyków zarówno krakowskich, jak i lwowskich.

To jednak nie koniec niespodzianek, które przyniósł pierwszy, niezbyt długi, bowiem obejmujący tylko jedną kartkę, list. W teście dwukrotnie padło nazwisko Antoniego Prochaski. Po raz pierwszy jako recenzenta książki Dorpat $i$ były uniwersytet dorpacki Manteuffla. Po raz drugi polsko-inflancki baron wymienił Prochaskę jako przyszłego sprawozdawcę z jego pracy Terra Mariana, któremu już przesłał jeden egzemplarz reprodukcji łacińskiej księgi. Co ciekawe, Prochaska, jak oświadczał Manteuffel Semkowiczowi: „na mój list nie odpisał”. Czy ostatecznie odpisał czy nie, nie wiadomo. Jednak do dwóch nowych kontaktów korespondencyjnych historyka z Drycan można z pewnością dodać jeszcze jedno nazwisko.

Drugi list jest jeszcze bardziej interesujący. Pismo datowane na 14 grudnia 1903 r. $^{12}$ Manteuffel rozpoczyna od życzeń z okazji zbliżających się świąt Bożego Narodzenia. Polsko-inflancki dziejopis po raz kolejny dziękuje za list z 24 września, tym razem jednak cytując fragment

${ }^{11}$ Zapis daty wygląda w tym liście następująco: „22/I 1903 r.”. Dlatego najprawdopodobniej list pochodzi z 22 listopada, a Manteuffel po prostu zgubił rzymską cyfrę „X”. Na „listopadową” proweniencję tekstu może również wskazywać pochodzenie pozostałych listów, gdyż w przypadku odczytania daty jako styczniowej pojawiałaby się prawie roczna przerwa, aż do grudnia, z następnymi listami. Bardziej logiczne wydaje się przypisanie go do niezbyt rozłożonej w czasie wymiany korespondencji. Wówczas zgadzałyby się również daty umieszczone w tekście.

12 Tym razem data zapisana została cyframi arabskimi. 
listu Semkowicza. Jest to bardzo ważne odkrycie, ponieważ umożliwia zapoznanie się z zapewne nieistniejącym, gdyż prawdopodobnie zniszczonym w czasie wojny tekstem. Dzięki temu odkryta korespondencja jest wyjątkowa, ponieważ raczej nie zachował się nawet spis listów do Manteuffla zgromadzonych w Bibliotece Narodowej przed II wojną światową. Już tylko z tego powodu konieczne wydaje się przytoczenie rzeczonego fragmentu listu w całości. Semkowicz 24 września 1903 r. miał pisać do Manteuffla: „Administrator i Skarbnik Tow. Hist. P. Dr Rolny wysłał JWPanu Baronowi trzy egzempl. Kwartalnika, w którym się praca Jego mieści, do księgarni Wendego i sp. w Warszawie, która otrzymała polecenie, aby każdy zeszyt Kwart. wysyłała pod adresem JWPana. Proszę przeto zwrócić się do tej księgarni z żądaniem dostarczenia zaległych zeszytów i dostarczanie regularnie zeszytów kwartałowych".

Jednak na tym nie kończą się walory informacyjne omawianego listu Manteuffla. Z cytowanego fragmentu można dowiedzieć się, jak wyglądało przesyłanie książek do Rygi. Z Galicji przekazywano je za pośrednictwem księgarzy warszawskich. Trzeba mieć przy tym na uwadze, że rosyjska administracja niechętnym okiem patrzyła na rodzinę Manteuffla, przynajmniej od czasów postania styczniowego, a jak wiadomo, pod obserwacją niektórzy pozostawali przez wiele, wiele lat ${ }^{13}$. Zanim jednak zostanie omówiona kwestia carskiej cenzury, warto jeszcze przez chwilę zatrzymać się na stosunkach Manteuffla z księgarzami, bowiem nie ze wszystkimi współpracował tak pomyślnie jak z poznaniakiem Janem Konstantym Żupańskim. Spółka księgarska Wendego najwidoczniej nie zaskarbiła sobie łask nadbałtyckiego arystokraty, o czym nie omieszkał poinformować redakcji „Kwartalnika Historycznego":

$\mathrm{Na}$ dowód jak spełnia owe łaskawe polecenia Szan. Redakcji księgarnia, załączam jej odpowiedź w oryginale, z uwagą żem do końca roku nie doczekał ani obiecanych trzech egzemplarzy zeszytu 3go z r. 1902 (w którym się mieści moja rozprawka, z jakiej zapowiadano wykonać obiecaną odbitkę), ani też zeszytów 3go i 4go z roku bieżącego 1903, co tem bardziej zastanawiać musi, żem owej księgarni udzielił dosłownie rozporządzenie Redakcyi.

${ }^{13}$ Na przykład po powstaniu listopadowym rodzina Platerów pozostawała pod nadzorem rosyjskich donosicieli jeszcze w 1838 r. Dlatego można sądzić, że Manteufflowie, którzy byli zaangażowani w działania styczniowej insurekcji w 1863 r., także znajdowali się pod obserwacją. Por. B. Breżgo, Odgłosy powstania 1830-1831 na Witebszczyźnie i Inflantach, w: Pamiętnik V Powszechnego Zjazdu Historyków Polskich w Warszawie, Lwów 1930, s. 384. 
Cóż takiego w odpowiedzi z Warszawy wzburzyło barona Manteuffla, nie wiadomo. Żadnego pisma księgarni Wendego wśród korespondencji administracji „Kwartalnika Historycznego” nie odnalazłem. Może został odesłany Manteufflowi wraz z kolejną korespondencją? Jednak list ze stolicy Królestwa Kongresowego musiał na Manteufflu sprawić niemiłe wrażenie. Na tyle niemiłe, że wywołał prócz - jak można się domyślać zrozumiałego - oburzenia, także wspomnienia z przeszłości. Po prawie pięćdziesięciu latach Manteuffel przypomniał sobie: „słowa dowcipnego prof. Hehna ${ }^{14}$, z czasów studiów moich uniwersyteckich w byłym Dorpacie". Jest to wyznanie o tyle istotne, że wcześniej nie było wiadomo, na jakie zajęcia w Dorpacie uczęszczał Manteuffel. Warto odnotować, że ta anegdotyczna wzmianka o czasach akademickich polsko-inflanckiego dziejopisa jest jednym z bardzo nielicznych tego typu świadectw pisanych przez samego Manteuffla ${ }^{15}$.

Wracając zaś do sprawy stosunków inflanckiego barona z rosyjską cenzurą, to list ten przynosi informacje nadzwyczajne. Okazuje się bowiem, że Gustaw Manteuffel, nieprzejednany wróg „azjatycko-barbarzyńskiego” zaborcy, potrafił bardzo dobrze ułożyć się z władzami cenzorskimi. Oczywiście wzmianka o tym, to jednocześnie przytyk do redakcji „Kwartalnika Historycznego", że ostatnio u nich we Lwowie działy się rzeczy niespotykane, jak niedosyłanie aktualnych numerów, ale przede wszystkim wskazuje na ugruntowaną pozycję Manteuffla w ryskim towarzystwie: „Przez lat kilkanaście z rzędu otrzymywałem regularnie Wasze cenne czasopismo, nawet w porze, kiedy wstęp jego był wzbroniony do Rosyi, gdyż cenzura dla mnie czyniła wyjątek wiedząc, że się nie zajmuję polityką ale nauką".

Zasadne wydaje się pytanie, kto w ryskiej cenzurze „czynił wyjątek" dla Gustawa Manteuffla? Czyżby któryś z jego dobrych znajomych? A może nawet ktoś z krewnych lub powinowatych? I dlaczego od pewnego momentu nawet jemu, człowiekowi nauki a nie polityki, cenzura zaczęła mieszać szyki? Rosjanie wiedzieli, że Manteuffel się „nie zajmuje polityką ale nauką" i dla niego czynili wyjątek. Jak to było możliwe, że wcześniej przez wiele lat tolerowali jego działalność? Jakim cudem mu się to udawało? Czyżby dzięki rodowym koneksjom z „całym klanem polskiego ziemiaństwa witebskiego, z najbłękitniejszą arystokracją niemiecką inflandzką i kurlandzką, jak niemniej z mnóstwem najwybitniejszych rodów niemieckich na Litwie", jak pisał o nim Czesław Jankowski ${ }^{16}$ ?

${ }^{14}$ Chodzi o Wiktora Hehna (zm. 1890 r. w Berlinie). W Dorpacie prowadził zajęcia m.in. z literatury niemieckiej.

${ }^{15}$ Nie zaliczam do nich opublikowanych w książce $Z$ dziejów Dorpatu i byłego Uniwersytetu Dorpackiego, Warszawa 1911.

16 Por. Cz. Jankowski, Dziejopis Inflant, „Tygodnik Ilustrowany” 1908, 2, s. 562. 
Jednak wymowa tych zdań Manteuffla była oczywista. Nawet Rosjanie nie utrudniają mu pracy, a w autonomicznej Galicji jest problem z przesłaniem mu dwóch czy trzech numerów czasopisma naukowego, w którym ponadto znajdowały się artykuły jego autorstwa. Z pewnością w tym duchu odczytał list Semkowicz, gdyż pod datą znajduje się odręczny dopisek ołówkiem: „Proszę wysłać wprost do M. i uwiadomić go o tem. Co sobie o nas pomyśli?!”.

Manteuffel nie dawał za wygraną i wierzył w to, że presja, ale wyrażona w sposób bardzo subtelny, ma sens. Miał rację, chociaż nie przewidział innych czynników, które stały na przeszkodzie jego zapoznaniu się z długo wyczekiwanymi numerami czasopisma. Jednak informacje o tym pochodzą już z trzeciego listu. Wysłał bowiem kolejny do Semkowicza już cztery dni później, to jest 18 grudnia 1903 r. Dziękował w nim za „uprzejme pismo” oraz wyrażał radość z faktu, że: „po tylu miesiącach oczekiwania, poczyna się do mnie uśmiechać perspektywa zaglądania nieco regularniej do «Kwartalnika»".

Tak więc Manteuffel wciąż jeszcze czasopisma nie otrzymał, ale jego nadzieje zostały podtrzymane. Najprawdopodobniej Semkowicz natychmiast po otrzymaniu listu Manteuffla odpisał baronowi, że sprawa została wyjaśniona i brakujące numery „Kwartalnika” wkrótce znajdą się na jego biurku w Rydze. Chociaż Manteuffel wolał nie ryzykować kontaktu z warszawską księgarnią Wendego, „która się z nieokrzesaną cenzurą warszawską uporać nie może, rzecz przewleka się do nieskończoności”. Poprosił więc Semkowicza, aby egzemplarze lwowskiego pisma przesłał pocztą bezpośrednio do niego.

Przy okazji zbliżających się świąt składał również „nasze staropolskie «Dosiego Roku» obok «Bóg zapłać!»”. Słowa te, tak głęboko zakorzenione w kulturze polskiej, były wyrazem łączności z nią Manteuffla, a przecież dla niego była ona kulturą przybraną, czy może lepiej - wybraną. Tylko i wyłącznie jego decyzją było, aby pisać po polsku, a nie po francusku, niemiecku, rosyjsku czy łotewsku. A przecież w dziewiętnastowiecznej Rydze to wypowiedzi w tych językach przyniosłyby mu sławę i sukces w postaci rozpowszechnienia jego prac. Decyzja o wyborze polszczyzny była w gruncie rzeczy fatalna dla samego Manteuffla, choć na szczęście zbawienna dla kultury polskiej. Brak większego zainteresowania Polaków tymi „Kresami kresów” (określenie za Dorotą Samborską-Kukućc17)

17 Por. D. Samborska-Kukuć, Wstęp, w: L.H. Plater, Dramat bez nazwy, Łódź 2015, s. 8. Jako „Kresy północne” określał Inflanty Polskie m.in. Andrzej Romanowski w: Pozytywizm na Litwie. Polskie życie kulturalne na ziemiach litewsko-białorusko-inflanckich $w$ latach 1864-1904, Kraków 2003, s. 333. 
spowodował, że prace inflanckiego badacza - jak i on sam - popadły w długie zapoznanie. Dopiero od stosunkowo niedawna wydobywani są na światło dzienne z bibliotecznych magazynów starych druków czy zapomnianych zespołów archiwalnych ${ }^{18}$.

Ostatnim, nieznanym listem Manteuffla odnalezionym podczas listopadowej kwerendy była pocztówka wysłana z Rygi 3 lutego 1904 r. Jest ten dokument o tyle ciekawy, że z braku koperty wiadomo, do kogo inflancki baron kierował tu swoje słowa, co nie zawsze wynikało z kontekstu wypowiedzi. Przy okazji uwidacznia się jeszcze kwestia wielojęzyczności Manteuffla, który znał przynajmniej kilka języków, a władał nimi z pewnością biegle, to jest oprócz wymienionego wcześniej języka łotewskiego: język państwowy - rosyjski, język niemiecki - wyniesiony z domu oraz wyuczona, dosyć późno, polszczyzna. W drugim liście znajdowały się wyrażenia w języku francuskim, języku ówczesnej arystokracji i inteligencji.

Zaangażowanie Semkowicza musiało przynieść pożądany skutek, bowiem Manteuffel na tej samej kartce informował, że „pan Dr Rolny wysłał mi pod rekomendowaną opaską w dniu 21 grudnia zeszłego roku 3 zeszyty "Kwartalnika»", załączając przy tym wyrazy wdzięczności. Zapewne inflancki dziejopis otrzymał już wspomniane egzemplarze, ale wciąż nie był zadowolony, czegoś znowu brakowało, choć tym razem wina nie leżała po stronie lwowian. Zmiana starych, z dawna już ułożonych stosunków nastąpiła w ryskiej cenzurze: „która jednak z powodów niedocieczonych, z każdego egzemplarza wydarła stronice 420-425 i 426-429". Sprawa byłaby zapewne zakończona, gdyby Manteuffel po ostatniej cyfrze postawił kropkę. Cała awantura z ryską cenzurą ma jednak ciąg dalszy i drugie dno. Kolejna informacja o zdekompletowanym egzemplarzu została bardzo małym druczkiem dopisana w poprzek kartki pocztowej z lewej strony: „Z 3ma egzempl. 3go zeszytu Kwart. z r. 1902 nadesłał łaskawie p. Dr Rolny 3 zeszyt Kw. z r. 1903, z którego niestety wyrwano strony 427 i 428, na których się mieści recenzya o książce Dorpat $i$ b. uniwersytet dorpacki, rzecz dla mnie ciekawa".

Cenzorzy widocznie działali według ściśle określonego planu, aby uniemożliwić, albo przynajmniej w znacznym stopniu utrudnić Manteufflowi dotarcie do oczekiwanych przez niego tekstów. Chociaż zapewne nie doceniali wagi swojego znakomicie skoligaconego i mającego rozległe kontakty przeciwnika. Okazuje się, że w starciu z Manteufflem cała

18 Chyba najbardziej wymownym dowodem tego twierdzenia jest editio posthuma długo uważanego za zaginiony tekstu Gustawa Manteuffla pt. Zarysy z dziejów krain dawnych inflanckich... przez Krzysztofa Zajasa w 2007 r., prawie sto lat po śmierci historyka z Drycan. 
rosyjska państwowa machina cenzuralna była, delikatnie mówiąc, bezskuteczna. Manteuffel zaś, jeżeli tylko chciał, mógł zapoznać się z tekstami, które były wówczas na terenie pod panowaniem Romanowów zakazane. Wspominał zresztą o tym już w jednym z poprzednich listów. Jak się wydaje, chodziło mu raczej o posiadanie kompletnego egzemplarza książki w swojej bibliotece, niż o możliwość zapoznania się z zawartością, którą w ten czy inny sposób w końcu by uzyskał. Jak bowiem inaczej wytłumaczyć słowa historyka, wykazującego się znajomością treści konkretnych stron czasopisma? Pisał on, że na usuniętych stronach „przy najlepszej chęci niepodobna dopatrzyć coś anticenzuralnego ${ }^{19}$. Chciejcie owe strony inkryminowane przejrzeć w Waszym całkowitym egzemplarzu dla przekonania się, iż nawet przy złej woli trudno tam odnaleźć coś politycznego lub antyrządowego".

Jeżeli otrzymał zdekompletowane numery „Kwartalnika”, to skąd miałby wiedzę o tym, czy są „cenzuralne” czy , anticenzuralne”? Oczywiście być może wcale nie widział na oczy owych inkryminowanych stron, być może ktoś znajomy z cenzury poinformował go, że nic strasznego tam się nie znajdowało, ale po prostu zostały one z nieznanych powodów wycięte. To pewnie jeszcze długo pozostanie tajemnicą. Manteuffel nie dostrzegał logiki w działaniu rosyjskich cenzorów, więcej, nie dostrzegał żadnego celu w wyrywaniu różnych stron $\mathrm{z}$ nadchodzących do niego czasopism. Było dla niego coś jeszcze gorszego niż „zła wola” - wola (a może niewola?) carskiego urzędnika.

Na szczęście absolwent prawa dyplomatycznego nie kończył swojej wiadomości całkowicie pesymistycznie. Więcej, przyszłość rysowała się w nieco jaśniejszych barwach, a to za sprawą mającej się ukazać recenzji „o reprodukcjach księgi Terra Mariana”. Ta myśl z pewnością napełniała Manteuffla otuchą, gdyż jego opus magnum było dla niego niesłychanie istotne. Dlatego obietnica ukazania się recenzji, prawdopodobnie pozytywnej, musiała cieszyć inflanckiego barona, który był głównym autorem koncepcji dzieła.

Odnalezione w zbiorach Biblioteki Uniwersytetu Lwowskiego cztery listy Gustawa Manteuffla do Aleksandra Semkowicza faktycznie nie wnoszą rewolucyjnych dodatków do biografii wybitnego badacza dziejów Inflant. Ich wartość polega głównie na uzupełnieniu „białych plam” jego dotychczasowych biografii, ustaleniu listy osób, z którymi utrzymywał kontakty. Ważnym jego korespondentem była redakcja lwowskiego „Kwartalnika Historycznego” oraz galicyjscy historycy polscy. Chociaż te skromne cztery teksty, pochodzące z przełomu 1903 i 1904 r., dotyczą

$19 \mathrm{Tj}$. niecenzuralnego, niedopuszczalnego dla cenzury. 
w zasadzie jednej kwestii - dostarczenia brakujących numerów czasopisma do Rygi, to jednak wzmianki poboczne w nich zawarte sprawiają, że obraz Manteuffla staje się bardziej ostry. Korespondencja ta przynosi informacje, jak technicznie rozwiązywano problem przekazywania periodyku do kraju, w którym był on zakazany. Co więcej, listy barona rzucaja też trochę światła na jego relacje z rosyjską cenzurą i stanowią dowód na to, że musiał mieć w tej instytucji niemałe wpływy lub, precyzyjniej, wysoko postawionych znajomych. Na uwagę zasługuje również krótka wzmianka na temat czasów studenckich Manteuffla w Dorpacie i wspomnienie o jednym $z$ uniwersyteckich profesorów.

\section{Streszczenie}

Historiograf województwa inflanckiego - Gustaw Manteuffel (1832-1916) - to postać powoli wydobywana z powszechnego zapomnienia. Dorobek historyka z Drycan obejmuje kilkaset tekstów dotyczących głównie dziejów, kultury, sztuki jego rodzinnych stron. Najbardziej znane prace tego autora to: Inflanty Polskie, Listy znad Bałtyku, Terra Mariana i wydane pośmiertnie Zarysy z dziejów krain dawnych inflanckich. Współpracował on również z wieloma redakcjami polskich wydawnictw naukowych z różnych zaborów. Rękopiśmienna spuścizna polsko-inflanckiego dziejopisa została prawie całkowicie zaprzepaszczona w czasie II wojny światowej w popiołach Biblioteki Narodowej w Warszawie. Badacze obecnie dysponują źródłami, które są rozproszone w kilku krajach (głównie w Polsce, ale też m.in. na Łotwie, Litwie, Ukrainie, w Niemczech). Niestety, do dziś nie istnieje obszerniejszy tekst podsumowujący życie i dzieło Gustawa Manteuffla. Najważniejszy biogram Manteuffla, opracowany przez Juliusza Bardacha (PSB), nie wymienia wielu źródeł, które udało się do tej pory odnaleźć. Autor artykułu w czasie kwerendy w Bibliotece Uniwersyteckiej we Lwowie odnalazł nieznaną część korespondencji badacza z redakcją „Kwartalnika Historycznego”. Odkrycie to pozwala uzupełnić w nieznacznym stopniu „białe plamy” w biografii barona Gustawa Manteuffla. Wśród tematów poruszanych w listach znajdują się m.in. informacje na temat rosyjskiego cenzurowania wydawnictw galicyjskich historyków, kwestie publikacji artykułów przez kresowego badacza, sprawy kolportażu „Kwartalnika” w Rydze. Dzięki odnalezionym listom można nieco poszerzyć krąg znajomości Manteuffla o kolejne postacie (np. Aleksandra Semkowicza, Wilhelma Rolnego).

\section{On Unknown Gustaw Manteuffel's Letters from the Collection of the Library of the University of L'viv. A Communiqué}

Gustaw Manteuffel (1832-1916), historian of the Livonian Province, has been gradually rescued from general oblivion. Achievements of the historian from Dricāni includes several hundred works on history, culture, and art of his native regions. 
His best-known texts are: Inflanty Polskie (Polish Livonia), Listy znad Bałtyku (Letters from the Baltic), Terra Mariana, and the posthumously published Zarysy z dziejów krain dawnych inflanckich (Outlines of the history of old Livonian countries). He also cooperated with editorial boards of many Polish scholarly periodicals in the three parts of the partitioned Polish-Lithuanian Commonwealth. Manteuffel's handwritten legacy had been almost completely lost during the Second World War in the ashes of the National Library in Warsaw. Today, at their disposal researchers have sources dispersed in several countries (mainly in Poland, but also in Latvia, Lithuania, Ukraine, and Germany). Unfortunately, a more comprehensive text summing up Gustaw Manteuffel's life has not yet been written. His most important biographic article, prepared by Juliusz Bardach for the Polish Biographical Dictionary, does not mention many source materials that have been found. During his search at the University Library in L'viv, the author of the present article found an unknown part of the correspondence exchanged between Manteuffel and the editorial board of the Kwartalnik Historyczny. This discovery makes it possible to fill some of the gaps in the biography of the Polish-Livonian baron. Among the various subjects taken up in the letters there are some pieces of information about Russians censoring publications by Galician historians, problems of Manteuffel's own publications and the question of Kwartalnik's distribution in Riga. It is also possible to broaden Manteuffel's circle of acquaintances through the inclusion of new people (such as, for example, Aleksander Semkowicz, Wilhelm Rolny).

Translated by Grażyna Waluga

\section{Bibliografia}

Bardach Juliusz, Manteuffel-Szoege Gustaw (1832-1916), PSB, t. 19, Kraków 1974, s. 491-493.

Breżgo Bolesław, Odgłosy powstania 1830-1831 na Witebszczyźnie i Inflantach, w: Pamiętnik V Powszechnego Zjazdu Historyków Polskich w Warszawie, Lwów 1930.

Danilewicz-Zielińska Maria, Wspomnienia o Bibliotece Narodowej w Warszawie, „Zeszyty Historyczne" Paryż 1987, 46.

Jankowski Czesław, Dziejopis Inflant, „Tygodnik Ilustrowany” 1908, 2, s. 562.

Manteuffel-Szoege Ryszard, Inflanty, Inflanty, oprac. Zbigniew Szopiński, Ludowa Spółdzielnia Wydawnicza, Warszawa 1991.

Romanowski Andrzej, Pozytywizm na Litwie. Polskie życie kulturalne na ziemiach litewsko-białorusko-inflanckich w latach 1864-1904, Universitas, Kraków 2003.

Samborska-Kukuć Dorota, Wstęp, w: Ludwika Hipolita Plater, Dramat bez nazwy, Primum Verbum, Łódź 2015.

Strods Henrihs, Gustaw Manteuffel (Manteuffel-Szoege, 1832-1916). Życie i twórczość, w: Kultura polska na Łotwie, red. Jarosław Sozański, Ryszard Szklennik, ARP, Ryga 1994.

Toczek Alfred, Lwowskie środowisko historyczne i jego wkład w kulturę książki i prasy (1860-1918), Wydawnictwo Naukowe Uniwersytetu Pedagogicznego, Kraków 2013. 
Zajas Krzysztof, Gustaw Manteuffel projektuje Inflanty, w: Gustaw Manteuffel, Inflanty Polskie i Listy znad Bałtyku, Universitas, Kraków 2009.

Zajas Krzysztof, Nieistniejąca kraina, zapomniany historyk, w: Gustaw Manteuffel, Zarysy z dziejów krain dawnych inflanckich..., oprac. Krzysztof Zajas, Universitas, Kraków 2007.

Biogra m: Radosław Budzyński, doktorant w Katedrze Międzynarodowych Studiów Polonistycznych na UJ. Studiował również bałtystykę na UW i w School of Slavonic and East European Studies na UCL. Jego zainteresowania naukowe obejmują północno-wschodnie tereny I RP, głównie dawnych Inflant. Tekst powstał jako rezultat kwerendy archiwalnej przeprowadzonej w zbiorach lwowskich instytucji naukowych w dn. 12-16 listopada 2017 r., dzięki wsparciu finansowemu dla doktorantów Wydziału Polonistyki UJ. E-mail: rad.budzynski@doctoral.uj.edu.pl. 